\title{
ANALISIS PENGARUH KUALITAS PRODUK, CITRA PERUSAHAAN DAN KEPERCAYAAN KONSUMEN TERHADAP KEPUASAN KONSUMEN PRODUK ON LINE
}

\author{
Marina Malian \\ Administrasi Negara, Sekolah Tinggi Ilmu Administrasi (STIA) Satya Negara Palembang \\ marinamalian@gmail.com
}

\begin{abstract}
Abstraks
Penelitian ini bertujuan untuk menganalisis secara parsial dan simultan pengaruh kualitas produk, citra merek dan kepercayaan konsumen dan terhadap kepuasan konsumen. Termasuk penelitian kuantitatif dengan menggunakan hasil survey kuesioner yang diisi responden. Sampel yang digunakan adalah 100 konsumen produk online di Palembang. Metode analisis data menggunakan analisis regresi linier berganda. Untuk menguji hipotesis pengaruh parsial variabel bebas terhadap variabel terikat digunakan uji t. Uji F digunakan untuk menguji pengaruh secara bersama-sama variabel bebas terhadap variabel terikat. Hasil pengolahan data menunjukkan terdapat pengaruh kualitas produk terhadap kepuasan konsumen. Kepercayaan konsumen berpengaruh terhadap kepuasan konsumen dan citra merek tidak berpengaruh terhadap kepuasan konsumen misalnya : kepuasan konsumen, kualitas produk, kepercayaan konsumen dan citra merek. Secara bersama-sama terdapat pengaruh variabel bebas terhadap variabel terikat. Kepercayaan konsumen berpengaruh paling dominan terhadap kepuasan konsumen produk on line.
\end{abstract}

Kata kunci : Kualitas produk, kepercayaan konsumen, citra merek, kepuasan konsumen

\begin{abstract}
This study aims to analyze partially and simultaneously the effect of product quality, brand image and consumer trust and on consumer satisfaction. Including quantitative research using the results of a questionnaire survey filled out by respondents. The sample used is 100 consumers of online products in Palembang. The data analysis method used multiple linear regression analysis. To test the hypothesis of the partial effect of the independent variables on the dependent variable, the t-test was used. The $F$ test is used to test the joint effect of the independent variables on the dependent variable. The results of data processing show that there is an effect of product quality on consumer satisfaction. Consumer trust affects consumer satisfaction and brand image does not affect consumer satisfaction, for example: consumer satisfaction, product quality, consumer trust and brand image. Taken together, there is an effect of the independent variable on the dependent variable. Consumer trust has the most dominant influence on consumer satisfaction for online products.
\end{abstract}

Keywords: Product quality, consumer trust, brand image, customer satisfaction 


\section{A. PENDAHULUAN}

Saat ini konsumen di Indonesia mulai menyukai berbelanja di toko online. Konsumen tidak harus pergi ke luar rumah, datang ke toko untuk membeli produk yang diinginkan. Seiring perkembangan dunia usaha yang kini berbasis digital. Hal ini disertai dengan tumbuhnya tokotoko online di buka jagad maya. Tawaran diskont, harga yang terjangkau, pilihan produk dan kemudahan untuk mendapatkan produk yang diinginkan menjadikan aktifitas berbelanja secara on line menjadi pilihan yang tepat terutama bagi konsumen yang ingin mendapatkan produk dengan mudah dan cepat. Produk yang ditawarkan toko online beraneka ragam dari produk kosmetik, gadget/it, buku, peralatan sekolah, alat travelling, tiket konser dan yang paling favorit adalah fashion.

Hasil penelitian yang telah dilakukan Kominfo beberapa masalah yang dihadapi dalam pembelian produk online adalah kualitas produk, keterlambatan atau barang tidak sampai, masalah keamanan transaksi pembayaran, tidak ada bantuan bila konsumen mengalami ke rugian, tidak tahu siapa yang bertanggung jawab serta hambatan kualitas layanan.

Perubahan dalam pola konsumtif konsumen mengharuskan perusahaan untuk giat berinovasi dan cermat dalam menilai dan mengetahui apa yang konsumen butuhkan serta inginkan. Perusahaan harus memiliki daya juang yang tinggi serta harus bisa mengerti kebutuhan konsumennya dengan baik, memiliki produk yang spesifikasi dan kualitasnya mumpuni namun harganya relatif terjangkau, karena konsumen saat ini sangatlah presisi dalam menentukan kualitas, harga dan brand apa yang bisa menarik perhatian di media sosial serta memiliki brand image atau citra merek yang baik dan mudah diingat (Geraldine \& Susanti, 2021). Beberapa factor yang mempengaruhi kepuasan konsumen dalam membeli produk yang ditawarkan secara online adalah kualitas produk, kepercayaan konsumen dan citra merek. Penelitian ini bertujuan untuk menganalisiss pengaruh secara parsial dan secara simultan kualitas produk, kepercayaan konsumen dan citra merek terhadap kepuasan konsumen produk On line. Penelitian ini juga menganalisis variabel yang paling berpengaruh terhadap kepuasan konsumen produk Online.

\section{a. Kepuasan Konsumen}

Menurut Kotler \& Amstrong, (2016) menyatakan definisi pemasaran adalah "proses dimana terciptanya nilai dari perusahaan bagi pelanggan dan dibangunnya hubungan yang kuat dengan pelanggan guna menangkap nilai dari pelanggan sebagai suatu imbalan". Griffin \& Ebert (2008) menyatakan bahwa "pemasaran dalah proses perencanaan dan pelaksanaan konsep, pemberian harga, promosi dan penyaluran ide-ide, barang dan jasa untuk menciptakan pertukaran yang memuaskan individu dan tujuan organisasi". Dari kedua pernyataan di atas dapat disimpulkan bahwa pemasaran adalah dimana sebuah perusahaan, baik produk maupun jasa berusaha semaksimal mungkin untuk memenuhi kebutuhan dan keinginan konsumen 
dengan menciptakan produk baru dan memberikan nilai yang sesuai.

Kepuasan adalah hasil penilian mengenai keistimewaan atau keunggulan suatu produk atau layanan dalam memenuhi keinginan atau harapan konsumen. Terdapat lima factor utama yang harus diperhatikan perusahaan dalam menentukan tingkat kepuasan konsumen (Lupiyadi (2001:160) yaitu : kualitas produk, kualitas pelayanan, emosional harga dan biaya. Menurut Tjiptono, (2006) kepuasan konsumen adalah: Merasa senang selama atau setelah melakukan pembelian, selalu melakukan pembelian produk atau layanan ini, Pilihan belanja yang paling tepat, Merekomendasikan. Indikator konsumen yang puas (Kotler, 2007:120) :

1. Melakukan pembelian ulang,

2. Merekomendasikan kepada pihak lain untuk membeli produk atau layanan yang telah memberikan kepuasan

3. Tidak memperhatikan iklan pesaing dan

4. Membeli produk lain dari merk yang sama

b. Kualitas Produk

Kotler \& Keller, (2016:30) Pemasaran adalah tentang mengidentifikasi dan memenuhi kebutuhan manusia dan sosial. Satu salah satu definisi terbaik dari pemasaran adalah memenuhi kebutuhan secara menguntungkan".Definisi tersebut dapat diartikan bahwa pemasaran adalah tentang Mengenal dan memenuhi kebutuhan manusia dan sosial. Lalu pemasaran adalah memenuhi kebutuhan secara menguntungkan.
Kotler \& Keller, (2016:402) kualitas produk merupakan kemampuan suatu produk untuk melakukan fungsi-fungsinya, kemampuan itu meliputi :

1. Daya tahan,

2. Kehandalan,

3 Ketelitian yang dihasilkan,

4. Kemudahan dioperasikan dan diperbaiki, dan

5. Atribut lain yang berharga pada produk secara keseluruhan.

\section{c. Kepercayaan Konsumen}

Kepercayaan konsumen dalam transaksi bisnis merupakan pertimbangan utama. Pada transaksi penjualan online tingkat kepercayaan ini semakin tinggi dibutuhkan. Kepercayaan konsumen dalam transaksi dalam bisnis online menjadi hal yang penting bagi konsumen karena konsumen tidak berhadapan langsung dengan penjual dan transaksi pengiriman barang akan dilakukan bila konsumen sudah mengirimkan uang ke penjual. Resiko konsumen menjadi korban penipuan lebih tinggi dibanding pembelian secara konvensional dimana konsumen bisa langsung berhadapan dengan penjual. Menurut Yousafzai et al., (2003) kepercayaan konsumen adalah kepercayaan yang dinyakini konsumen bahwa penjual akan memenuhi kewajiban sesuai yang diharapkan. Indikator kepercayaan menurut Nurnaini (2009) adalah :

1. Kejujuran Penjual dalam bertransaksi

2. Tanggung jawab penjual kepada pembeli

3. Kepercayaan bahwa perusahaan memiliki reputasi yang baik. 
Penelitian yang telah dilakukan Susilowati, (2015) menunjukkan hasil bahwa Kepercayaan pelanggan terbukti mempunyai pengaruh yang signifikan terhadap kepuasan pelanggan dalam bisnis online.

\section{d. Citra Merk}

Menurut Kotler dan Keller (2009:258) merk merupakan nama, istilah, symbol, tanda, rancangan atau kombinasi dari semua hal di atas untuk mengidentifikasikan atau member cirri khas tertentu yang membedakan produk tersebut dengan produk pesaing. Citra merek merupakan seperangkat keyakinan konsumen mengenai merek tertentu, seperti asosiasi yang tertanam di memori konsumen (Kotler dan Amstrong, 2008:225). Dengan citra merek yang baik suatu produk akan mudah diingat dan mudah dalam mengevaluasi kinerja produk.

Menurut Tjiptono, (2006) perlu dipenuhi syarat-syarat agar tujuan pemberian merek dapat tercapai. Syarat-syarat tersebut antara lain :

1. Merk harus bersifat unik dan khas. Mempunyai suatu cirri khusus yang membedakan dengan merk lainnya.

2. Merek mengandung sesuatu yang menggambarkan manfaat dan produknya.

3. Merk harus mudah dikenali, mudah diingat dan diucapkan

4. Merk harus mengandung arti atau konotasi yang baik dalam bahasa disuatu Negara atau diluar Negara tersebut.

Menurut Sondakh, (2014) merk memegang peranan penting dalam persaingan bisnis saat ini karena dapat membedakan produk atau perusahaan dengan produk atau perusahaan lainnya. Indikator merk adalah ;

1. Penampilan fisik dan kesan yang profesional

2. Kesan yang modern

3. Merek yang dikenal dimasyarakat

4. Merek yang mudah diingat

5. Kebanggaan kepada merek

Hipotesis penelitian sebagai berikut :

1. Terdapat pengaruh kualitas produk terhadap kepuasan konsumen produk online di Palembang

2. Terdapat pengaruh kepercayaan konsumen terhadap kepuasan konsumen produk online di Palembang

3. Terdapat pengaruh citra merek terhadap kepuasan konsumen produk on line di Palembang

4. Terdapat pengaruh secara bersama-sama kualitas produk, kepercayaan konsumen dan citra merek terhadap kepuasan konsumen produk on line di Palembang

5. Kepercayaan Konsumen berpengaruh paling besar terhadap kepuasan konsumen produk on line di Palembang

Peta persaingan bisnis semakin meningkat tajam, preferensi dan perilaku pelanggan berubah, teknologi informasi berkembang dengan cepat mendorong organisasi bisnis untuk lebih fokus menanggapi kepuasan pelanggan untuk menjamin pengembangan dan berkelanjutan bisnis. Disaat persaingan semakin ketat, produsen berusaha memenuhi kebutuhan dan keinginan konsumen dengan menawarkan 
berbagai jenis produknya, dampaknya konsumen memiliki banyak pilihan, kekuatan tawar-menawar konsumen semakin besar, yang mendorong setiap perusahaan harus menempatkan orientasinya pada kepuasan pelanggan selanjutnya mendapatkan kepercayaan sebagai tujuan utamanya (Sariffudin, 2017).

\section{B. METODE}

Penenelitian ini merupakan penelitian penjelasan yang bersifat kuantitatif bersumber dari pengolahan data kuisioner. Penelitian ini menjelaskan hubungan variabel bebas pengaruhnya terhadap variabel terikat. Populasi dari penelitian ini adalah konsumen produk online di Palembang. Metode pengambilan sampel dalam penelitian ini menggunakan purposive sampling yaitu pengambilan anggota sample berdasarkan kreteria tertentu. Adapun kreteria tertentu yang dijadikan sampel adalah Konsumen yang pernah membeli produk OnLine. Di ambil sampel 100 orang .

Jenis data yang digunakan adalah data primer yaitu data dari hasil pengolahan kuisioner yang telah diisi responden. Kuisioner berisi pertanyaan dan pernyataan. Pertanyaan data diri responden, frekwensi pembelian produk online, toko yang sering dikunjungi, produk yang sering dibeli dan alasan membeli produk OnLine. Berdasarkan pengalaman setelah melakukan transaksi produk online, responden diminta mengisi kuisioner yang berisi pernyataan-pernyataan untuk mengukur pengaruh variabel kualitas produk, kepercayaan konsumen dan citra merek. Data sekunder diperoleh dari sumber lain yang berkaitan dengan masalah yang diteliti.

Tehnik analisis data yang digunakan adalah :

1. Uji Validitas dan Uji Reliabilitas Instrumen

2. Methode Successive Interval (MSI)

Data yang diperoleh dari hasil survey dengan menggunakan skala likert merupakan data ordinal. Agar data ordinal tersebut bisa di analisiss dengan regresi berganda perlu ditransformasikan ke data interfal. MSI merupakan Metode yang digunakan untuk mengubah data yang bersifat ordinal ke interval (Suliyanto, 2005:25).

3. Analisis Linier Berganda Persamaan regresi dapat dilihat sebagai berikut:

$Y=a+1 X_{1}+2 X_{2}+3 X_{3}+e$

Keterangan:

$\mathrm{Y}=$ Kepuasan Konsumen

$\mathrm{a}=$ Konstanta

$\mathrm{X}_{1}=$ Kualitas produk

$\mathrm{X}_{2}=$ Kepercayaan Konsumen

$\mathrm{X}_{3}=$ Citra Merek

1- 5 = Koefisien regresi

4. Pengujian Hipotesis secara parsial :

Keterangan:

$\mathrm{t} \quad=$ Nilai t hitung

bi = Koefisien regresi

Sbi = Kesalahan baku koefisien regresi atau

gambar deviasi

Rumusan hipotesis:

: I < 0 Secara parsial tidak terdapat pengaruh antara variabel kualitas produk (X1), kepercayaan konsumen ( $\left.\mathrm{X}_{2}\right)$, dan citra merek (X3) terhadap kepuasan konsumen $(\mathrm{Y})$. 
: $\mathrm{i}>0$ Secara parsial terdapat pengaruh antara variabel kualitas produk ( $\left.\mathrm{X}_{1}\right)$, kepercayatho konsumen $\left(X_{2}\right)$, dan citra merek $\left(X_{3}\right)$ terhadap kepuasan konsumen $(\mathrm{Y})$.

Kriteria pengujian:

Ho ditolak jika t hitung $>\mathrm{t}$ tabel

Ho diterima jika $\mathrm{t}$ hitung $\leq \mathrm{t}$ table

$\mathrm{Ha}$

5. Pengujian hipotesis dengan uji $F$ untuk menguji pengaruh secara simultan.

Tujuan uji F adalah untuk mengetahui derajat signifikan pengaruh variabel-variabel independen kualitas produk ( $\left.\mathrm{X}_{1}\right)$, kepercayaan konsumen $\left(\mathrm{X}_{2}\right)$, dan citra merek (X3) terhadap kepuasan konsumen $(\mathrm{Y})$.

Uji $\mathrm{F}$ dengan cronbach 0,05 atau $95 \%$ menggunakan rumus Arikunto (2010:65) :

$$
\begin{aligned}
& R^{2} /\left(\begin{array}{ll}
k & 1
\end{array}\right) F \\
& \left(\begin{array}{ll}
1 & R^{2}
\end{array}\right) /\left(\begin{array}{lll}
n & k & 1
\end{array}\right) \\
& \mathrm{F} \quad=\text { Nilai } \mathrm{F} \text { hitung } \\
& \mathrm{R}^{2} \quad=\text { Koefisien determinasi } \\
& \mathrm{K}=\text { = Jumlah variabel bebas } \\
& \mathrm{N} \quad=\text { Jumlah Sampel }
\end{aligned}
$$

Rumusan hipotesis:

$: 1,2,3=0$ Secara simultan tidak terdapat pengaruh signifikan dari variabelvariabel bebas kualitas produk (X1), kepercayaan konsumen $\left(\mathrm{X}_{2}\right)$, dan citra merek (X3) terhadap kepuasan konsumen (Y).

$: 1,2,3=0$ Secara simultan terdapat pengaruh signifikan dari variabelvariabel bebas kualitas produk $\left(\mathrm{X}_{1}\right)$, kepercayaan konsumen $\left(\mathrm{X}_{2}\right)$, dan citra merek $\left(\mathrm{X}_{3}\right)$ terhadap kepuasan konsumen (Y).

Kriteria pengujian:

Ho ditolak jika $\mathrm{F}$ hitung $>\mathrm{F}$ tabel

Ho diterima jika F hitung $\leq \mathrm{F}$ table

\section{HASIL PENELITIAN DAN PEMBAHASAN}

a. Hasil Penelitian

1. Data Responden

Data responden berdasarkan Jenis kelamin, umur, pekerjaan, frekwensi pembelian, produk yang dibeli dan toko on line yang sering dikunjungi adalah sebagai berikut :

Tabel 1. Data karekteristik Responden

\begin{tabular}{lcc}
\hline Karekteristik & Jumlah & Presentase \\
\hline A. Jenis kelamin: & & \\
1. Laki-laki & 26 & $26 \%$ \\
\hline B. Umur: & & \\
1. $17-23$ tahun & 54 & $54 \%$ \\
2. $24-30$ tahun & 26 & $26 \%$ \\
3. $31-37$ tahun & 12 & $12 \%$ \\
4. 37 tahun $<$ & 8 & $8 \%$ \\
\hline
\end{tabular}


C. Pekerjaan :

1. Pelajar/Mahasiswa

$46 \%$

2. PNS

3. Pegawai Swasta

4. Wiraswasta

5. Ibu rumah Tangga

10 $10 \%$

D. Frekwensi Pembelian Produk On Line :

1. 1- 4 kali

2. $5-10$ kali

3. 10 kali $<$ 30

E. Produk On Line yang sering dibeli

1. Fashion

2. Buku dan perlengkapan sekolah

3. Gadget

4. Makanan/minuman

5. Kosmetik

14

$14 \%$

F. Toko On line yang sering untuk membeli :

1. Toko Pedia

2. Bukalapak 16 $16 \%$

3. Shophee 40 $40 \%$

4. Face Book 8 $8 \%$

5. Instagram 8 $8 \%$ Sumber : Data yang diolah 


\section{Sumber : Data yang diolah}

Berdasar tabel di atas bahwa responden mayoritas berjenis kelamin perempuan. Hal ini karena perempuan mempunyai waktu lebih banyak untuk berbelanja dibanding lakilaki. Umur responden paling banyak usia 1723 tahun karena pasar terbesar produk on line adalah dari kalangan kaum muda. Pekerjaan responden paling banyak dari pelajar atau mahasiswa dan pegawai swasta. Umumnya responden sudah berulangkali membeli produk online. Produk yang sering dibeli terbanyak adalah produk fashion, kosmetik, buku dan perlengkapan sekolah,

makanan dan minuman, gadget serta spare part kendaraan. Toko online yang sering dikunjungi responden adalah Shophee, Toko pedia, Bukalapak, Face book, Instagram dan lain-lain. Alasan responden membeli produk online antara lain karena harga murah, mudah tidak harus keluar rumah, praktis, efisien, banyak pilihan, tidak ditemukan di kota Palembang, barang bagus, sudah terbiasa beli produk online.
2. Uji Normalitas, Uji Multikolinearitas dan homoskedastisitas

Nilai signifikansi dari hasil uji normalitas lebih besar dari 0,05, maka dapat disimpulkan bahwa model regresi dalam penelitian ini berdistribusi normal. Semua variabel bebas kualitas produk $\left(\mathrm{X}_{1}\right)$, kepercayaan konsumen $\left(\mathrm{X}_{2}\right)$, dan citra merek $\left(\mathrm{X}_{3}\right)$ mermempunyai nilai toleransi di atas 0,1 dan nilai VIF di bawah 10, sehingga dapat disimpulkan bahwa model regresi pada penelitian ini tidak terjadi multikolinearitas. Tingkat signifikansi untuk masing-masing variabel independen terhadap absolute residualnya adalah lebih dari 0,05. Hal ini berarti seluruh variabel independen tersebut tidak signifikan mempengaruhi absolute residualnya yang dapat disimpulkan bahwa data memenuhi asumsi homoskedastisitas.

\section{Analisis Linier Berganda}

Berdasarkan pengolahan data dengan SPSS diperoleh persamaan regresi linier berganda sebagai berikut

Tabel 2. Coeffisients

\section{Coefficients $^{a}$}

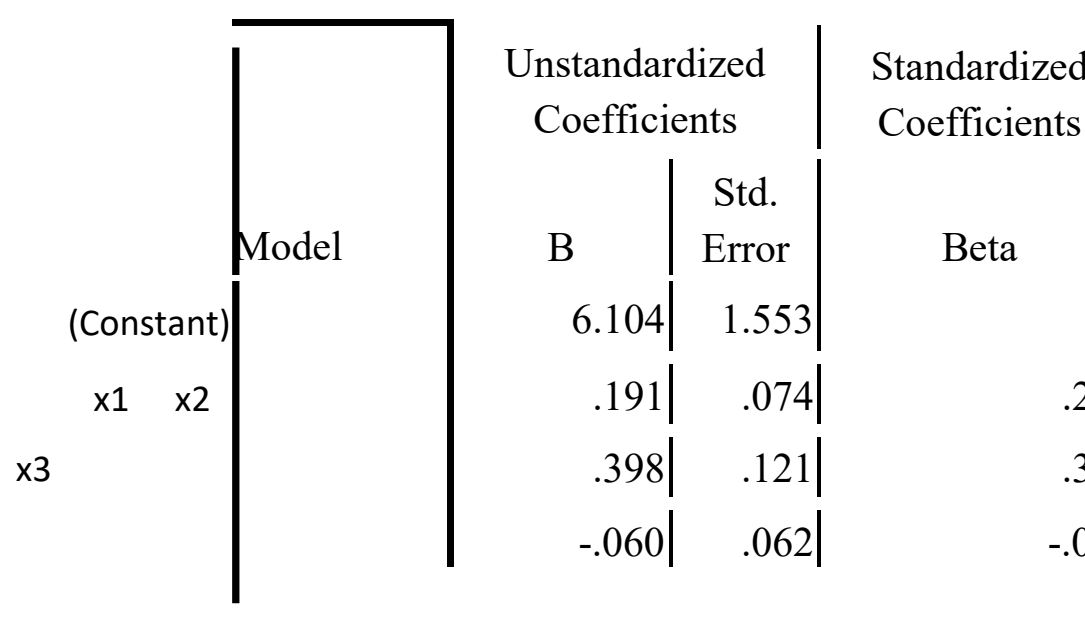

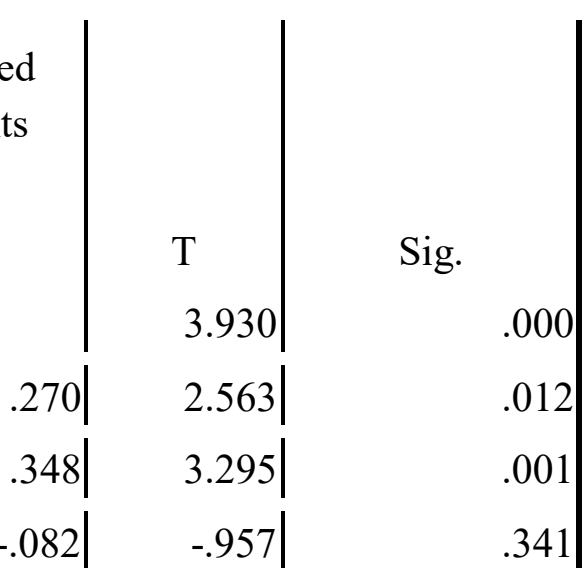

Available online at https://ejournals.umma.ac.id/indeks.php/point 
Berdasarkan persamaan regresi tersebut dapat diartikan bahwa kondisi konstan kepuasan konsumen $(\mathrm{Y})$ sebelum ada pengaruh kualitas produk (X1), kepercayaan konsumen ( $\left.\mathrm{X}_{2}\right)$, dan citra merek $\left(\mathrm{X}_{3}\right)$ bernilai positif yaitu 6.104 . Apabila kualitas produk (X1) naik satu satuan maka kepuasan konsumen ( $Y$ ) akan naik dengan nilai kenaikan sebesar 0,191, jika kepercayaan konsumen (X2) naik satu satuan maka kepuasan konsumen $(\mathrm{Y})$ akan ikut naik dengan nilai tambahan 0,398 , jika citra merek (X3) naik satu satuan turun maka kepuasan konsumen (Y) akan turun dengan nilai penurunan 0,060 .

Dari persamaan regresi linier berganda diatas dapat diketahui bahwa kualitas produk dan kepercayaan konsumen mempunyai hubungan yang positif terhadap kepuasan konsumen. Citra merk mempunyai hubungan negatif dengan kepuasan konsumen.

4. Pengujian hipotesis dengan uji $t$ dan uji $F$ diperoleh hasil sebagai berikut :

a. Pengaruh kualitas produk terhadap kepuasan konsumen produk Online di Palembang

Berdasarkan hasil pengolahan data diperoleh nilai t hitung 2,563 dengan jumlah responden 100 orang diperoleh $t$ tabel dengan $d f: 100-3=$ 97 pada taraf signifikansi 5\% sebesar 1,98498 .sehingga $t$ hitung $>t$ tabel $(2,563>1,98498)$, serta $p$-value $=0,012$ lebih kecil dari $\alpha=$ 0,05 , maka dapat disimpulkan ada pengaruh yang signfikan kualitas produk terhadap kepuasan konsumen produk on line di Palembang. Dengan demikian hipotesis 1 yang menyatakan terdapat pengaruh kualitas produk terhadap kepuasan konsumen diterima. b. Pengaruh kepercayaan konsumen terhadap kepuasan konsumen produk Online di Palembang.

Berdasarkan hasil pengolahan data diperoleh nilai t hitung 3,295 dengan jumlah responden 100 orang diperoleh $t$ tabel dengan $d f: 100-3=97$ pada taraf signifikansi $5 \%$ sebesar 1,98498 , sehingga $t$ hitung $>\mathrm{t}$ tabel $(3,295>1,98498)$, serta $p$ value $=0,001$ lebih kecil dari $\alpha=0,05$, maka dapat disimpulkan ada pengaruh yang signfikan kepercayaan konsumen terhadap kepuasan konsumen produk on line di Palembang. Dengan demikian hipotesis 2 yang menyatakan terdapat pengaruh kepercayaan konsumen terhadap kepuasan konsumen diterima.

c. Pengaruh kepercayaan konsumen terhadap kepuasan konsumen produk Online di Palembang

Berdasarkan hasil pengolahan data diperoleh nilai t hitung - 0,957 dengan jumlah responden 100 orang diperoleh $t$ tabel dengan $d f: 100-3=97$ pada taraf signifikansi $5 \%$ sebesar 1,98498 sehingga $t$ hitung $<\mathrm{t}$ tabel $(-0,957<1,98498)$, serta $p$-value $=0,341$ lebih besar dari $\alpha=0,05$, maka dapat disimpulkan tidak ada pengaruh yang signfikan citra merek terhadap kepuasan konsumen produk online di Palembang. Dengan demikian hipotesis 3 yang menyatakan terdapat pengaruh citra 
merek terhadap kepuasan konsumen ditolak.

d. Pengaruh secara bersama-sama kualitas produk, kepercayaan konsumen dan citra merek terhadap kepuasan konsumen produk on line di Palembang

Untuk menguji pengaruh secara bersama-sama variabel bebas terhadap variabel terikat digunakan uji F. Penelitian dengan jumlah responden 100 dan variabel bebas 3 maka $F$ tabel adalah 2,70. Berdasarkan tabel 3 diperileh hasil nilai $F$ hitung 13.70 dengan signifikansi 0,00. F hitung lebih besar dari $F$ tabel $(13,70>2,70)$ dengan sig $=0.000<0,05$. Berarti Hipotesis 4 yang menyatakan terdapat pengaruh secara bersama-sama kualitas produk, kepercayaan konsumen dan citra merek terhadap kepuasan konsumen produk online di Palembang diterima.

\section{Tabel 3. Uji F}

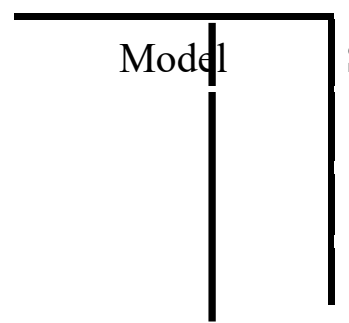

$$
\begin{array}{r}
\text { Sum of Squares } \\
223.980 \\
522.020 \\
746.000
\end{array}
$$

\section{ANOVA ${ }^{b}$}

\begin{tabular}{r|r|c|} 
Df & Mean Square & $\mathrm{F}$ \\
3 & 74.660 & 13.730 \\
96 & 5.438 & \\
99 & &
\end{tabular}

Sig.

.000

Regression Residual

Total

a. Predictors: (Constant), $x 3, \times 1, \times 2$

b. Dependent Variable: $y$ 
e. Kepercayaan Konsumen berpengaruh paling besar terhadap kepuasan konsumen produk on line di Palembang.

Berdasarkan tabel Coeffisiens, kepercayaan konsumen mempunyai pengaruh paling besar mempengaruhi kepuasan konsumen produk online di Palembang dibandingkan variabel kualitas produk dan citra merek. Hipotesis ke lima yang menyatakan Kepercayaan Konsumen berpengaruh paling besar terhadap kepuasan konsumen produk online di Palembang diterima.

\section{b. Pembahasan}

1. Pengaruh kualitas produk terhadap kepuasan konsumen produk On line di Palembang Berdasarkan hasil pengolahan data diperoleh nilai $\mathrm{t}$ hitung 2,563 dan $\mathrm{t}$ tabel dengan $d f$ : 100-3= 97 pada taraf signifikansi 5\% sebesar 1,98498 .sehingga $t$ hitung $>t$ tabel $(2,563>$ 1,98498 ), serta $p$-value $=0,012$ lebih kecil dari $\alpha=0,05$, maka dapat disimpulkan ada pengaruh yang signfikan kualitas produk terhadap kepuasan konsumen produk on line di Palembang. Hasil penelitian ini mendukung penelitian Wibowo, (2009) Diansyah, (2016) bahwa kualitas produk berpengaruh terhadap kepuasan konsumen. Penelitian ini juga memperkuat pendapat dari Naser et al (1999) bahwa kepuasan pelanggan sangat tergantung pada bagaimana tingkat kualitas produk yang ditawarkan. Hasil penelitian ini tidak jauh berbeda dengan hasil penelitian yang dilakukan Endraswati, (2007) bahwa kepuasan pelanggan ditentukan tingkat kinerja produk. Bila tingkat kinerja produk sesuai atau melebihi harapan konsumen maka konsumen akan merasa puas dan sebaliknya. Penelitian yang telah dilakukan Susilowati, (2015) menunjukkan hasil bahwa kualitas produk mempunyai pengaruh yang signifikan terhadap kepuasan pelanggan dalam bisnis online.

Menurut Haryanto, (2013) Strategi promosi, kualitas produk, kualitas layanan secara bersama-sama berpengaruh terhadap kepuasan pelanggan pada Restoran Cepat Saji mcDonald's Manado, sehingga hipotesis yang menyatakan bahwa diduga variabel Strategi promosi, kualitas produk, kualitas layanan secara bersama-sama berpengaruh terhadap kepuasan pelanggan pada Restoran Cepat Saji mcDonald's Manado diterima.

2. Pengaruh kepercayaan konsumen terhadap kepuasan konsumen produk Online di Palembang

Berdasarkan hasil pengolahan data diperoleh nilai t hitung 3,295 dengan jumlah responden 100 orang diperoleh $t$ tabel dengan $d f: 100-3$ $=97$ pada taraf signifikansi 5\% sebesar 1,98498 , sehingga $t$ hitung $>t$ tabel $(3,295>$ $1,98498)$, serta $p$-value $=0,001$ lebih kecil dari $\alpha=0,05$, maka dapat disimpulkan ada pengaruh yang signfikan kepercayaan konsumen terhadap kepuasan konsumen produk on line di Cilacap. Penelitian yang telah dilakukan Susilowati, (2015) menunjukkan hasil bahwa Kepercayaan pelanggan terbukti mempunyai pengaruh yang signifikan terhadap kepuasan pelanggan dalam bisnis online. 
Hasil penelitian ini mendukung penelitian yang dilakukan Arifin, (2011) Wahyuningsih et al., (2013) dimana hasil penelitiannya menunjukkan kepercayaan berpengaruh positif dan signifikan terhadap kepuasan pelanggan.

Bertransaksi secara online mempunyai resiko lebih besar dibandingkan berrtansaksi secara manual di toko dimana pembeli bertemu langsung dengan penjualnya. Konsumen harus mengirimkan uang terlebih dahulu sebelum barang yang dipesan datang. Bila penjual berniat tidak baik dapat dengan mudah uang sudah diterima barang tidak dikirim atau barang tidak sesuai pesanan. Kepercayaan konsumen bahwa produsen bersikap jujur, bertanggung jawab akan kewajibannya sesuai sengan harapan konsumen.

3. Pengaruh Citra merek terhadap kepuasan konsumen produk Online di Palembang Berdasarkan hasil pengolahan data diperoleh nilai $t$ hitung - 0,957 dengan jumlah responden 100 orang diperoleh $\mathrm{t}$ tabel dengan $d f: 100-3=97$ pada taraf signifikansi $5 \%$ sebesar 1,98498 sehingga $t$ hitung $<\mathrm{t}$ tabel $(-0,957<1,98498)$, serta $p$-value $=0,341$ lebih besar dari $\alpha=0,05$, maka dapat disimpulkan tidak ada pengaruh yang signfikan citra merek terhadap kepuasan konsumen produk online di Palembang. Penelitian ini berbeda dengan hasil penelitian Diansyah, (2016) bahwa citra merek berpengaruh positif dan signifikan terhadap kepuasan konsumen. Penelitian ini mendukung hasil penelitian yang dilakukan Sondakh, (2014) yaitu citra merek tidak berpengaruh terhadap kepuasan nasabah karena citra merek itu sudah melekat dalam pikiran nasabah. Demikan juga pada penelitian ini sebagian besar responden tidak memperhatikan citra merek. Responden merasa puas membeli produk online karena mendapatkan kemudahan untuk mendapatkan barang yang diinginkan mempunyai banyak pilihan produk, banyak promo dan harga terjangkau.

4. Pengaruh secara bersama-sama kualitas produk, kepercayaan konsumen dan citra merek terhadap kepuasan konsumen produk on line di Palembang

Untuk menguji pengaruh secara bersamasama variabel bebas terhadap variabel terikat digunakan uji F. Penelitian dengan jumlah responden 100 dan variabel bebas 3 maka $F$ tabel adalah 2,70. Berdasarkan tabel 3 diperileh hasil nilai $F$ hitung 13.70 dengan signifikansi 0,00. $F$ hitung lebih besar dari $F$ tabel $(13,70>2,70)$ dengan sig $=0.000<0,05$. Hasil penelitian ini mendukung hasil temuan Diansyah, (2016) bahwa kualitas produk dan citra merek secara bersama-sama berpengaruh terhadap kepuasan konsumen.

5. Kepercayaan Konsumen berpengaruh paling besar terhadap kepuasan konsumen produk online di Palembang

Berdasarkan tabel Coeffisiens, kepercayaan konsumen mempunyai pengaruh paling besar mempengaruhi kepuasan konsumen produk online di Palembang dibandingkan 
variabel kualitas produk dan citra merek. Hipotesis ke lima yang menyatakan Kepercayaan Konsumen berpengaruh paling besar terhadap kepuasan konsumen produk online di Palembang diterima.

Dasar paling utama terjadinya transaksi bisnis online adalah adanya kepercayaan konsumen terhadap kejujuran dan tanggung jawab penjual sesuai harapan pembeli. Pembeli yang tidak percaya khawatir ditipu menjadi penyebab gagalnya proses penjualan.

\section{PENUTUP}

\section{Simpulan}

Dari Hasil penelitian mengenai Analisis Pengaruh Kualitas Produk, Citra Perusahaan dan Kepercayaan Konsumen Terhadap Kepuasan Produk Online yaitu Kualitas produk berpengaruh terhadap kepuasan konsumen produk online di Palembang, Kepercayaan konsumen berpengaruh terhadap kepuasan konsumen produk online di Palembang, Citra merek tidak berpengaruh terhadap kepuasan konsumen produk online di Palembang, Terdapat pengaruh secara bersama-sama kualitas produk, kepercayaan konsumen dan citra merek terhadap kepuasan konsumen produk online di Palembang, Kepercayaan Konsumen berpengaruh paling besar terhadap kepuasan konsumen produk online di Palembang

\section{Saran}

Dari hasil penelitian yang diperoleh dari 100 responden konsumen produk Online rata-rata memberikan respon yang baik terhadap kualitas produk, citra perusahaan dan kepercayaan konsumen. Penulis menyarankan agar perusahaan meningkatkan kualitas produksi Online, dan menjaga citra perusahaan agar perusaahaan tetap mampu bersaing dengan perusahaan produk Online yang lainnya. dan bagi penelitian selanjutnya Pada penelitian ini menunjukan bahwa kepuasan konsumen mengintervening pengaruh kualitas produk terhadap loyalitas konsumen dalam bentuk mediasi sebagian (partial mediation), yang artinya ada variabel- variabel lain yang bisa dijadikan sebagai variabel intervening pengaruh kompensasi terhadap kinerja karyawan. Peneliti menyarankan untuk penelitian selanjutnya agar mengembangkan lagi penelitian ini dengan mempertimbangkan variabel-variabel lain seperti harga, biaya dan kemudahan yang mungkin berpengaruh terhadap kepuasan terhadap loyalitas. Peneliti juga menyarankan untuk mempertimbangkan penambahan variabel moderator untuk penelitian selanjutnya. Sampel yang digunakan dalam penelitian ini terbilang sedikit, untuk penelitian selanjutnya diharapkan dapat memperbanyak sampel yang akan digunakan, sehingga akan mendekati gambaran hasil yang lebih mendekati kondisi yang sesungguhnya dan diharapkan juga untuk menggunakan jenis perusahaan lain sebagai objek penelitian.

\section{E. DAFTAR PUSTAKA}

Arikunto, Suharsimi. (2010). Manajemen Penelitian. Rineka Cipta, Jakarta

Arifin, S. (2011). Pengaruh Kepercayaan, Fasilitas dan Kualitas Pelayanan Terhadap Kepuasan Konsumen Pada 
Hotel Jepara Indah. Jurnal Dinamika Ekonomi \& Bisnis, 8(1), 67-78. https://doi.org/10.34001/jdeb.v8i1.10 1

Diansyah. (2016). Pengaruh Kualitas Produk dan Citra Merek Terhadap Kepuasan konsumen Laptop Lenovo Dengan Inovasi Produk Sebagai Variabel Moderating. Media Studi Ekonomi, 19(2), 43-55. http://journal.uta45jakarta.ac.id/inde x.php/MSE/article/viewFile/561/343

Endraswati. (2007). Mutu Produk, Nilai dan Kepuasan Pelanggan dalam Pandangan Islam. In Marketing Mix Extra. Jakarta.

Geraldine, Y. M., \& Susanti, A. (2021). Pengaruh Citra Merek, Kualitas Produk, Media Sosial Dan Harga Terhadap Minat Beli Konsumen Pada Produk Brand Wardah. POINT: Jurnal Ekonomi Dan Manajemen, 3(1), 71-82. https://doi.org/10.46918/point.v3i1.8 80

Haryanto, R. A. (2013). Strategi Promosi, Kualitas Produk, Kualitas Layanan Terhadap Kepuasan Pelanggan Pada Restoran Mcdonald's Manado. Jurnal Riset Ekonomi, Manajemen, Bisnis Dan Akuntansi, 1(4), 1465-1473. https://doi.org/10.35794/emba.v1i4.2 923

Kotler, \& Amstrong, G. (2016). Dasar-Dasar Pemasaran, Jilid 1 Edisi Kesembilan ( $\mathrm{p}$. 125). Jakarta: Erlangga.

Kotler, Philip, \& Keller, K. L. (2016). Manajemen Pemasaran, Edisi 13 Jilid 2. Jakarta: Erlangga.

Kotler, Phillip, \& Keller, K. L. (2016). Manajemen Pemasaran, Edisi 12 Jilid 1 \& 2. Jakarta: PT. Indeks.

Sarifuddin. (2017). Pengaruh Kualitas Produk Terhadap Citra Perusahaan Dan Kepuasan Serta Dampaknya Pada Kepercayaan Konsumen Mobil Toyota Avanza Di Kota Palu. Jurnal Katalogis,
5(7), 191-216. http://jurnal.untad.ac.id/jurnal/index. php/Katalogis/article/view/9667

Sondakh, C. (2014). Kualitas Layanan, Citra Merek Dan Pengaruhnya Terhadap Kepuasan Nasabah Dan Loyalitas Nasabah Tabungan (Studi Pada Nasabah Taplus BNI Cabang Manado). Jurnal Riset Bisnis Dan Manajemen, 3(1), 19-32. https://ejournal.unsrat.ac.id/index.ph $\mathrm{p} / \mathrm{jrbm} /$ article/view/7525

Suliyanto. (2005). Analisis Data dalam Aplikasi Pemasaran. Bogor: Ghalia Indonesia.

Susilowati. (2015). Faktor-Faktor Yang Mempengaruhi Kepuasan Pelanggan dalam Bisnis Online. Jurnal Komunikasi, 6(1), 28-36.

Tjiptono, F. (2006). Manajemen Jasa, Edisi Pertama. Yogyakarta: Andi.

Wahyuningsih, E., Winarti, C., \& Prihandini, D. (2013). Pengaruh Pelayanan Prima, Kepercayaan, dan Kepuasan terhadap Loyalitas Nasabah Tabungan PT. Bank Mandiri (Persero), Tbk. di Jakarta Pusat. Jurnal Ilmiah.

Wibowo, A. (2009). Analisis Pengaruh Kualitas Produk terhadap Kepuasan Pelanggan (Studi pada Perumahan Sembungharjo Permai Pengembang PT. Sindur Graha Tama). Jurnal Sains Pemasaran Indonesia, 8(2), 173-186. https://doi.org/10.14710/jspi.v8i2.173 $-186$

Yousafzai, S., Pallister, J. G., \& Foxall, G. R. (2003). A Proposed Model of E-Trust for Electronic Banking. Technovation, 23(11), 847-860. https://doi.org/10.1016/S01664972(03)00130-5

Nadhril Adabi. (2020). Pengaruh citra merek, kualitas pelayanan dan kepercayaan konsumen terhadap keputusan pembelian indihome di witel telkom depok. Jurnal Manajemen. Vol. 12 (1) 
2020, Hal. 32-39.

http://journal.feb.unmul.ac.id/index.p hp/JURNAL MANAJEMEN

Nuriyana, Fatati, Sucipto, dan Shyntia Atica Putri. (2014). Analisis Pengaruh Kualitas Produk Dan Brand Images Terhadap Kepuasan Konsumen Untuk Meningkatkan Loyalitas Konsumen Teh Botol Sosro. Jurnal Alumni Jurusan Teknologi Industri Pertanian, FTP - Univ. Brawijaya dan Dosen Jurusan Teknologi Industri Pertanian, FTP - Univ. Brawijaya. Tjiptono

Wijayanti, T. 2012. Pengaruh Relationship Marketing Terhadap Kepuasan Pelanggan Pada Asuransi Jiwa Bersama (AJB) Bumi Putera 1912 Cabang Purworejo 2012. 